\title{
HUBUNGAN EVALUASI AKREDITASI DAN IKLIM ORGANISASI DENGAN MOTIVASI DAN KINERJA GURU DI KECAMATAN SINTANG
}

\author{
Usman Adi \\ Pengawas SD / MI Kecamatan Dedai, Sintang \\ Email: Usmanadi@gmail.com
}

\begin{abstract}
The performance of teachers is one of the factors that determine the quality of basic education, There are two factors that affect the performance of teachers, namely internal factors and factors of external motivation is organiasasi climate and of accreditation. This study uses a quantitative approach that aims to explain the of the accreditation assessment (X1) and organization climate (X2), motivation (X3) and teacher performance $(Y)$. This research was conducted in primary schools the District Sintang with a population of 700 with a sample of 255 teachers, the sampling technique used in the study using questionnaires, then the data analysis technique used is descriptive analysis and path analysis using the help of a computer application SPSS 16.0 for Windows.The results of the study are as follows; (1) the accreditation assessment in primary schools the District Sintang included in both categories with the average - average 140.43; (2) organizational climate in the District elementary school Sintang included in both criteria with an average of 54.96; (3) motivation of teachers in primary schools included in the criteria the District Sintang high with an average value of 51.77; (4) the performance of teachers in primary schools the District Sintang included in the criteria very well with an average value of 93.95; (5) there is a direct relationship element - the element of the accreditation assessment of the performance of teachers in schools with grades path coefficient 0.299; (6) there is an indirect relationshi accreditation assessment by working through the motivation of teachers in schools with the coefficient of 0.165 lines, as well as relationships totaling $0.394 ;(7)$ there is no direct relationship of organizational climate with the performance of teachers in schools with the greatest path coefficientvalue of $0.012 ;(8)$ there is an indirect relationship with the school organization climate performance through motivation of teachers in schools with the coefficient of 0.218 lines, and the relationship of the total is 0.23 ; (9) there is a direct relationship of motivation with the performance of teachers in schools with the value of the path coefficient 0,470 .
\end{abstract}

Keywords: Evaluation accreditation, organization climate, motivation, teacher performance

ISSN: $2540-8038$ 


\begin{abstract}
Abstrak
Kinerja guru merupakan salah satu faktor yang menentukan kualitas pendidikan dasar, Terdapat dua faktor yang mempengaruhi kinerja guru, yaitu faktor internal motivasi dan faktor dari ekternal yaitu iklim organiasasi dan evaluasi akreditasi. Rumusan masalah pada penelitian ini yaitu. Penelitian ini menggunakan pendekatan kuantitatif yang bertujuan untuk menjelaskan evaluasi akreditasi $\left(\mathrm{X}_{1}\right)$ dan iklim organisasi $\left(\mathrm{X}_{2}\right)$, dengan motivasi $\left(\mathrm{X}_{3}\right)$ dan kinerja guru $(\mathrm{Y})$. Penelitian ini dilakukan di sekolah dasar Kecamatan Sintang dengan populasi berjumlah 700 dengan jumlah sampel 255 guru, teknik pengambilan sampel yang digunakan dalam penelitian menggunakan instrumen angket, kemudian teknik analisis data yang digunakan adalah analisis deskriptif dan analisis jalur menggunakan bantuan aplikasi komputer SPSS 16.0 for Windows. Hasil penelitian adalah sebagai berikut; (1) evaluasi akreditasi di sekolah dasar Kecamatan Sintang termasuk dalam kategori baik dengan rata - rata 140,43; (2) iklim organisasi di sekolah dasar Kecamatan Sintang termasuk dalam kriteria baik dengan rata-rata 54,96; (3) motivasi guru di sekolah dasar Kecamatan Sintang termasuk dalam kriteria tinggi dengan nilai rata-rata 51,77; (4) kinerja guru di sekolah dasar Kecamatan Sintang termasuk dalam kriteria sangat baik dengan nilai ratarata 93,95; (5) terdapat hubungan langsung evaluasi akreditasi dengan kinerja guru di sekolah dengan nilai koefisien jalur 0,299; (6) terdapat hubungan tidak langsung evaluasi akreditasi dengan kerja melalui motivasi guru di sekolah dengan nilai koefisien jalur 0,165, serta hubungan total sebesar 0,394 ; (7) tidak terdapat hubungan langsung iklim organisasi dengan kinerja guru di sekolah dengan nilai koefisien jalur terbesar 0,$012 ;(8)$ terdapat hubungan tidak langsung iklim organisasi sekolah dengan kinerja melalui motivasi guru di sekolah dengan nilai koefisien jalur 0,218 , serta hubungan totalnya adalah 0,23 ; (9) terdapat hubungan langsung motivasi dengan kinerja guru di sekolah dengan nilai koefisien jalur 0,470.Berdasarkan hasil penelitian tersebut saran yang diajukan adalah sebagai berikut; (1) bagi Assesor Badan Akreditasi Nasional SD/MI, Hendaknya Assesor Badan Akreditasi SD/MI mempertahankan evaluasi akreditasi serta lebih menyempurnakan lagi instrumen penilaian akreditasi tersebut; (2) bagi kepala sekolah dasar, sebaiknya kepala sekolah memahami setiap tahapan akreditasi, kemudian memberikan fasilitas, motivasi dan supervisi kepada guru untuk terus meningkatkan kinerjanya; (3) bagi guru sekolah dasar, hendaknya guru selalu memiliki motivasi untuk bekerja dengan baik, selalu mencari sumber belajar untuk meningkatkan kemampuan yang dimiliki sehingga kualitas pembelajaran akan meningkat; (4) bagi peneliti lainnya, sebaiknya bagi para peneliti yang akan melakukan penelitian tentang faktor yang mempengaruhi kinerja guru menambahkan variabel lain yang belum diteliti seperti pemberian reward atau punishment untuk meningkatkan kinerja guru, serta melakukan penelitian dalam lingkup yang lebih luas.
\end{abstract}

Kata kunci:Evaluasi Akreditasi, Organisasi, Motivasi, Kinerja guru. 


\section{A. Pendahuluan}

Pendidikan

merupakan

kebutuhan bagi manusia, dalam kehidupan berbangsa bernegara pendidikan memegang peranan penting dalam semua aspek kehidupan. Oleh karena itu untuk membentuk suatu negara yang maju dan kuat dibutuhkan pendidikan yang berkualitas.Salah satu bentuk dari pendidikan berkualitas adalah melalui sekolah. Jenjang pendidikan terdiri dari pendidikan dasar, pendidikan menengah dan pendidikan tinggi. Sebelum peserta didik menempuh pendidikan menengah dan pendidikan tinggi, diperlukan pendidikan dasar yang berkualitas.

Salah satu faktor yang menentukan kualitas pendidikan dasar adalah kinerja guru. Menurut Mangkunegara (2007:9) kinerja adalah "hasil kerja secara kualitas dan kuantitas yang dicapai oleh seorang pegawai dalam melaksanakan tugas sesuai dengan tanggung jawab yang diberikan kepadanya", dalam pengertian tersebut terdapat dua hal yang penting yaitu berkaitan dengan kualitas dan kuantitas yang dicapai oleh pegawai, dalam konteks ini merupakan guru. Terdapat dua faktor yang mempengaruhi kinerja guru yang pertama adalah faktor dari dalam diri sendiri (internal) dan faktor dari luar (eksternal). Bufford dan Bederian (1988:33) merinci faktor yang meliputi kinerja antara lain yaitu abilities, motivations, dan roles clarity. Salah satu faktor dari kinerja adalah kemampuan guru (abilities) untuk mengukur atau mengawasi hal tersebut salah satu kontrol atau pengawasan yang dilakukan oleh pemerintah untuk menyelenggarakan pendidikan dasar yang berkualitas adalah dengan melakukan sistem penjaminan mutu. Akreditasi sekolah merupakan salah satu bentuk pengawasan dari pemerintah dalam standarisasi kualitas layanan pendidikan. Menurut undang-undang nomor 20 tahun 2003 tentang Standar Pendidikan Nasional akreditasi adalah "kegiatan penilaian kelayakan program dalam satuan pendidikan berdasarkan kreteria yang telah ditetapkan“. Pengertian tersebut menunjukkan bahwa akreditasi merupakan suatu proses penjaminan mutu yang dilakukan oleh pemerintah dalam rangka melakukan kontrol terhadap 
kualitas program di setiap satuan pendidikan.

Evaluasi kelayakan program atau akreditasi mencakup delapan aspek strandar nasional yang tercantum dalam Peraturan Pemerintah Nomor 32 tahun 2013 Tentang Perubahan Atas Peraturan Pemerintah Nomor 19 Tahun 2005 Tentang Standar Nasional Pendidikan yaitu "Lingkup Standar Nasional Pendidikan meliputi : Standar Isi, Standar Proses, Standar Kompetensi Lulusan, Standar Pendidik dan Tenaga Kependidikan, Standar Sarana dan Prasarana, Standar Pengelolaan, Standar Pembiayaan, dan Standar Penilaian Pendidikan". Salah satu aspek dari standar tersebut yang harus dicapai adalah standar Pendidik dan tenaga kependidikan, sekolah yang sudah terakreditasi akan memiliki guru yang dari segi kuantitas dan kualitas memenuhi standar yang telah ditetapkan oleh pemerintah. Pada instrumen akreditasi tersebut tenaga pendidik harus menguasi empat kompetensi guru yaitu kompetensi pedagogik, kepribadian, profesional dan sosial.

Faktor yang kedua yang mempengaruhi kinerja guru adalah motivasi. Menurut Robbins (2001:208) Motivasi adalah "satu proses yang menghasilkan suatu intensitas, arah, dan ketekunan individual dalam usaha untuk mencapai suatu tujuan”. Dari pengertian tersebut dapat dipahami bahwa motivasi merupakan upaya dari individu atau kemauan untuk mencapai hal yang telah ditetapkan. Terdapat beberapa teori tentang motivasi, salah satu adalah teori hierarki kebutuhan Maslow yang diungkapkan oleh Tyson dan Jackson (1992:21) kebutuhan tersebut meliputi "pemenuhan diri, harga diri, sosial, stabilitas keamanan dan fisik". Dari hal tersebut dapat disimpulkan bahwa kinerja dari pendidikan salah satunya dipengaruhi oleh pemenuhan kebutuhan.

Faktor yang ketiga yang mempengaruhi kinerja guru adalah iklim organisasi sekolah Davis dan Newstroom

mendefinisikan iklim organisasi sekolah adalah "lingkungan dimana mereka melakukan pekerjaan”. Lingkungan mereka melakukan pekerjaan adalah organisasi di sekolah.Iklim organisasi sekolah merupakan salah satu faktor yang berpengaruh terhadap kinerja guru atau 
pendidik, banyak terdapat guru yang berhasil didukung oleh iklim organisasi di sekolah yang bagus dan memberikan kesempatan untuk mengembangkan diri, begitu pula sebaliknya banyak guru yang gagal karena iklim organisasi disekolahnya yang kurang mendukung. Mencermati kondisi tersebut maka penulis tertarik untuk meneliti tentang "Hubungan Evaluasi Akreditasi dan Iklim Organisasi dengan Motivasi dan Kinerja Guru di Sekolah Dasar Kecamatan Sintang”.

\section{B. Metode}

Penelitian ini adalah penelitian kuantitatif dengan menggunakan paradigma jalur. Paradigma jalur adalah "model hubungan antar variabel yang terbentuk sebab akibat. Dengan demikian dalam model hubungan antar variabel tersebut, terdapat variabel independen yang disebut variabel eksogen dan variabel dependen yang disebut dengan endogen Sugiyono, (2010: 297)".Rancangan dalam penelitian ini adalah sebagai berikut.

Gambar 3.1 Rancangan Penelitian

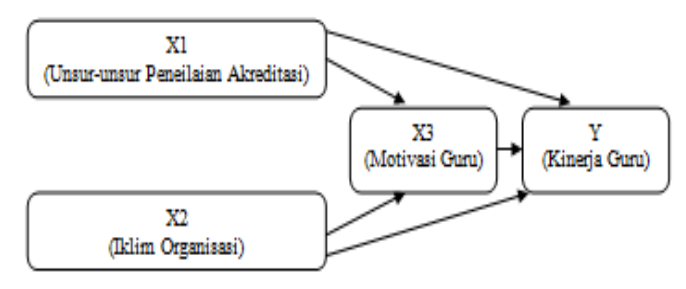

Populasi dari penelitian ini meliputi semua tenaga pendidik di sekolah dasar Kecamatan Sintangyang berjumlah 700 orang dan Teknik pengambilan sampel yang digunakan dalam penelitian ini adalah simple random sampling atau sampel secara acak.Penentuan jumlah sampel penelitian ini dengan menggunakan formula Slovin (Setyadin, 2005:19). Formula Slovin adalah sebagai berikut:

$$
n=\frac{N}{1+N(e)^{2}}
$$

keterangan :

$\mathrm{N}=$ Ukuran populasi

$\mathrm{n}=$ Ukuran sampel

$\mathrm{e}=$ toleransi peluang error, 0,05

Dari penggunaan formula slovin tersebut hasil yang diperoleh dari jumlah total keseluruhan populasi tenaga pendidik di sekolah dasar 
Kecamatan Sintang adalah sebagai berikut

$$
n=\frac{700}{1+700(0,0)^{2}}=254,54
$$

Jadi jumlah sampel yang diambil dalam penelitian ini adalah 255 guru.

Metode pengumpulan data yang digunakan dalam penelitian ini adalah dengan metode angket,Penelitian ini menggunakan jenis angket tertutup yaitu "angket dimana jawaban telah disediakan oleh peneliti yang kemudian dijawab oleh responden sesuai dengan keadaan responden tersebut" (Arikunto, 2006:151).Penelitian metode ini dilakukan untuk memperoleh data tentang pengaruh akreditasi dan iklim organisasi sekolah terhadap motivasi dan kinerja guru di sekolah dasar Kecamatan Sintang.

\section{Pembahasan dan Hasil}

Deskripsi Evaluasi Akreditas

\begin{tabular}{ccccc}
\hline $\mathbf{N}$ & $\begin{array}{c}\text { Inter } \\
\text { val }\end{array}$ & $\begin{array}{c}\text { Klasifik } \\
\text { Kelas }\end{array}$ & $\begin{array}{c}\text { Frekue } \\
\text { nsi }\end{array}$ & $\begin{array}{c}\text { Persent } \\
\text { ase (\%) }\end{array}$ \\
\hline 1 & $\begin{array}{c}\text { (4- } \\
61,4\end{array}$ & $\begin{array}{c}\text { Tidak } \\
\text { baik }\end{array}$ & 0 & 0 \\
\hline 2 & $61,5-$ & Kurang & 0 & 0 \\
\hline 3 & $89-9$ & baik & & \\
\hline
\end{tabular}

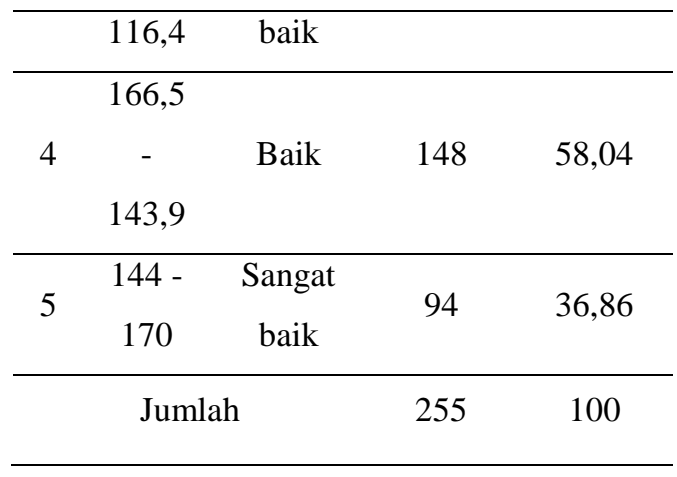

Berdasarkan tabel tersebut dapat diketahui dari 255 responden, 13 guru memiliki persepsi yang cukup baik terhadap evaluasi akreditasi dengan persentase sebesar 5,1\%, kemudian 148 guru mempunyai persepsi yang baik terhadap evaluasi akreditasi dengan persentase sebesar $58,04 \%$, dan 94 guru memiliki persepsi sangat baik terhadap evaluasi akreditasi atau sebesar $36,86 \%$.

Hasil tersebut menunjukkan bahwa guru mempersepsi baik tentang evaluasi akreditasi yang disusun oleh Badan Akreditasi Nasional (2009) yaitu unsur komponen standar isi, komponen standar proses, komponen standar kompetensi lulusan, komponen standar pendidik dan tenaga kependidikan, komponen standar sarana dan prasarana, komponen standar pengelolaan, komponen standar pembiayaan, dan komponen standar penilaian. 
Hasil tersebut diperkuat oleh pendapat Imron (2012: 34) Fungsi akreditasi antara lain untuk pengetahuan, yakni dalam rangka mengetahui kelayakan \& kinerja sekolah dilihat dari berbagai unsur yang terkait, mengacu kepada baku kualitas yang dikembangkan berdasarkan indikator-indikator sekolah yang baik (good school). Untuk akuntabilitas, yakni agar sekolah dapat mempertanggungjawabkan apakah layanan yang diberikan memenuhi harapan atau keinginan masyarakat. Untuk kepentingan pengembangan, yakni agar sekolah dapat melakukan peningkatan kualitas atau pengembangan berdasarkan masukan dari hasil akreditasi. Pernyataan ini mendukung hasil penelitian yang menunjukkan bahwa guru memiliki persepsi yang baik tentang evaluasi akreditasi, sehingga layanan yang diberikan sekolah terhadap masyarakat dapat dipertanggungjawabkan.

Deskripsi Frekuensi Iklim Organisasi Sekolah

\begin{tabular}{ccccc}
\hline No & $\begin{array}{c}\text { Interv } \\
\text { al } \\
\text { Kelas }\end{array}$ & $\begin{array}{c}\text { Klasifik } \\
\text { asi }\end{array}$ & $\begin{array}{c}\text { Frekue } \\
\text { nsi }\end{array}$ & $\begin{array}{c}\text { Persent } \\
\text { ase (\%) }\end{array}$ \\
\hline 1 & $\begin{array}{c}14- \\
25,4\end{array}$ & $\begin{array}{c}\text { Sangat } \\
\text { Rendah }\end{array}$ & 0 & 0 \\
\hline 2 & $\begin{array}{c}25,5- \\
36,9\end{array}$ & Rendah & 0 & 0 \\
\hline 3 & $\begin{array}{c}37- \\
48,4\end{array}$ & Sedang & 2 & 0,78 \\
\hline 4 & $\begin{array}{c}48,5- \\
59,9\end{array}$ & Tinggi & 121 & 47,45 \\
\hline 5 & $\begin{array}{c}60- \\
71,4\end{array}$ & $\begin{array}{c}\text { Sangat } \\
\text { Tinggi }\end{array}$ & 132 & 51,77 \\
\hline \multicolumn{5}{c}{ Jumlah } \\
\hline
\end{tabular}

Berdasarkan tabel tersebut dapat dikelahui dari 255 responden, 2 guru memiliki motivasi yang tinggi dengan persentase sebesar 47,45\%, dan 132 guru memiliki motivasi yang sangat tinggi atau sebesar 51,77\%,

Hasil penelitian tersebut dapat disimpulkan bahwa iklim organisasi tempat responden bekerja baik. Iklim organisasi yang baik akan membuat para guru nyaman bekerja sehingga tujuan organisasi dapat tercapai. Hal tersebut dipengaruhi dimensi iklim organisasi yang dikemukakan oleh Litwin dan Stringer dalam Toulson dan Smith (1994:457) dimensi iklim organisasi terdiri dari tanggung jawab, identitas, kehangatan, dukungan dan konflik. Iklim organisasi yang baik akan mempengaruhi kinerja guru 
seperti yang diungkapkan oleh Taiguri dan Litwin dalam Wiraman, (2007:121) "Iklim orgranisasi merupakan kualitas lingkungan internal organisasi yang secara relatif terus berlangsung, dialami oleh anggota organisasi dan mempengaruhi perilaku mereka serta dapat dilukiskan dalam satu set karakteristik atau sifat organisasi”.

\section{Deskripsi Motivasi Guru}

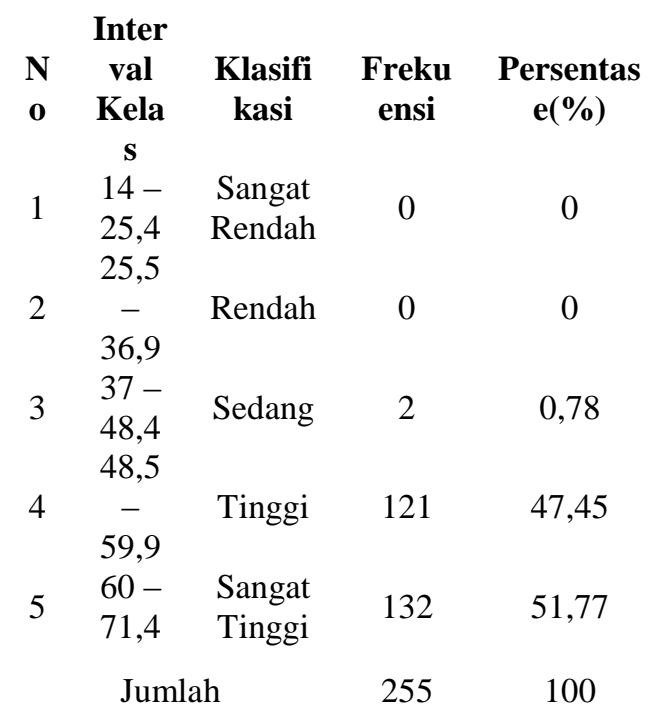

Berdasarkan tabel tersebut dapat diketahui dari 255 responden, 2 guru memiliki motivasi yang tinggi dengan persentase sebesar 47,45\%, dan 132 guru memiliki motivasi yang sangat tinggi atau sebesar $51,77 \%$.

Hasil tersebut menunjukkan bahwa guru di sekolah dasar Kecamatan Sintang memiliki motivasi yang tinggi. Hal tersebut tentu saja sangat baik untuk mencapai tujuan organisasi dan membuat guru memiliki kinerja yang baik seperti yang diungkapkan oleh Robbins (2003:208) "motivasi adalah satu proses yang menghasilkan suatu intensitas, arah, dan ketekunan individual dalam usaha untuk mencapai satu tujuan".

Deskripsi Kinerja Guru

\begin{tabular}{|c|c|c|c|c|}
\hline $\begin{array}{l}\mathbf{N} \\
\mathbf{o}\end{array}$ & $\begin{array}{c}\text { Inter } \\
\text { val } \\
\text { Kela } \\
\text { s } \\
\end{array}$ & $\begin{array}{c}\text { Klasifi } \\
\text { kasi }\end{array}$ & $\begin{array}{c}\text { Freku } \\
\text { ensi }\end{array}$ & $\begin{array}{c}\text { Persentas } \\
\text { e }(\%)\end{array}$ \\
\hline 1 & $\begin{array}{l}22- \\
39,8\end{array}$ & $\begin{array}{c}\text { Tidak } \\
\text { baik }\end{array}$ & 0 & 0 \\
\hline 2 & $\begin{array}{c}39,9 \\
- \\
57,7 \\
\end{array}$ & $\begin{array}{c}\text { Kurang } \\
\text { baik }\end{array}$ & 0 & 0 \\
\hline 3 & $\begin{array}{c}57,8 \\
- \\
75,6 \\
\end{array}$ & $\begin{array}{l}\text { Cukup } \\
\text { baik }\end{array}$ & 7 & 2,74 \\
\hline 4 & $\begin{array}{c}75,7 \\
- \\
93,5\end{array}$ & Baik & 116 & 45,49 \\
\hline 5 & $\begin{array}{c}93,6- \\
110 \\
\end{array}$ & $\begin{array}{c}\text { Sangat } \\
\text { baik }\end{array}$ & 132 & 51,77 \\
\hline \multicolumn{3}{|c|}{ Jumlah } & 255 & 100 \\
\hline
\end{tabular}

Berdasarkan tabel tersebut dapat diketahui dari 255 responden, 7 guru memiliki kinerja yang cukup baik dengan persentase sebesar 2,74\%, kemudian 116 guru mempunyai kinerja yang baik dengan persentase sebesar 45,49\%, dan 132 guru memiliki kinerja yang sangat baik atau sebesar $51,77 \%$. 
Hasil penelitian ini menunjukkan bahwa kinerja guru di sekolah dasar Kecamatan Sintang baik. Hal tersebut dipengaruhi oleh kemampuan guru dalam melakukan perencanaan program kegiatan pembelajaran, pelaksanaan kegiatan pembelajaran, evaluasi, komunikasi dan kedisiplinan. Hasil penelitian tersebut juga diperkuat oleh pendapat yang dikemukakan oleh Uno (2010:94) yang mengungkapkan bahwa terdapat dimensi yang berkaitan dengan kinerja guru sekolah dasar, diantaranya adalah "kualitas kerja, ketepatan kerja, inisiatif dalam kerja, kemampuan kerja dan komunikasi”. Menurut pendapat Prawirosentono (2010:2) mengartikan kinerja sebagai "hasil kerja yang dapat dicapai oleh seseorang atau sekelompok orang dalam suatu organisasi sesuai dengan tanggung jawab masing-masing dalam rangka upaya mencapai tujuan organisasi bersangkutan secara legal, tidak melanggar hukum dan sesuai dengan moral etika".

Hubungan Langsung Evaluasi Akreditasi (X1) dengan Kinerja Guru (Y)
Hasil analisis hipotesis statistik $\left(\mathrm{H}_{0}\right)$ hubungan langsung evaluasi akreditasi dengan kinerja guru dengan jumlah sampel 255 diperoleh $r_{\text {hitung }} 0,539$ dengan taraf signifikansi 5\%, hasil perhitungan koefisien jalur menunjukkan bahwa nilai standardized coefficient beta sebesar 0,229 dengan nilai signifikansi $0,000<0,05$. Kesimpulan yang dapat diambil dari hasil tersebut adalah Hipotesis $\left(\mathrm{H}_{0}\right)$ ditolak dan Hipotesis alternatif $\left(\mathrm{H}_{1}\right)$ diterima, maka terdapat hubungan langsung evaluasi akreditasi dengan kinerja guru.

Hasil tersebut sesuai dengan pendapat Wirawan (2009:7) lebih merincikan lagi tentang faktor yang berpengaruh pada kinerja guru, faktor tersebut meliputi faktor lingkungan internal organisasi, faktor lingkungan eksternal dan faktor internal.

Gambar 1. Informasi terkait gambar atau grafikPembahasan dalam artikel bertujuan untuk: (1) menjawab rumusan masalah dan pertanyaanpertanyaan penelitian; menunjukkan bagaimana temuantemuan tersebut diperoleh; (3) menginterpretasikan/ menafsirkan 
temuan-temuan yang diperoleh; (4) mengaitkan hasil temuan penelitian dengan struktur pengetahuan yang telah mapan; dan (5) memunculkan teoriteori baru atau modifikasi teori yang telah ada.

\section{Hubungan Tidak Langsung Evaluasi} Akreditasi $\left(\mathrm{X}_{1}\right)$ dengan Kinerja melalui Motivasi Guru $\left(\mathbf{X}_{\mathbf{3}}\right)$

Hubungan evaluasi akreditasi dengan motivasi guru sebesar 0,653 dengan taraf signifikansi $5 \%$ hasil perhitungan koefisien jalur menunjukkan bahwa nilai standardized coeffcient beta sebesar 0,347 dengan nilai signifikansi $0,000<0,05$ kemudian hubungan motivasi dengan kinerja guru diperoleh hasil 0,625 dengan taraf signifikansi $5 \%$, hasil koefisien jalur menunjukkan nilai koefisien jalur sebesar 0,475. Hubungan tidak langsung variabel $\mathrm{X}_{1}$ dengan $\mathrm{Y}$ melalui $\mathrm{X}_{3}$ adalah $0,347 \mathrm{x}$ $0,475=0,165$, hubungan total variabel $\mathrm{X} 1$ dengan $\mathrm{Y}$ adalah $0,165+0,229=$ 0,394 .

Hasil tersebut diperkuat oleh pendapat Imron (2012:32) fungsi akreditasi antara lain untuk pengetahuan, yakni dalam rangka mengetahui kelayakan dan kinerja sekolah dilihat dari berbagai unsur yang terkait, mengacu kepada baku kualitas yang dikembangkan berdasarkan indikator-indikator sekolah yang baik (good school). Salah satu standard akreditasi adalah standard ketenagaan, manfaat hasil akreditasi bagi guru menurut Badan Akreditasi provinsi Jakarta (BAP S/M) (2011) sebagai dorongan untuk selalu meningkatkan diri dan bekerja keras dalam memberikan layanan terbaik bagi peserta didik guna meningkatkan dan mempertahankan mutu sekolah.

\section{Hubungan Langsung Iklim Organisasi $\left(\mathrm{X}_{2}\right)$ dengan Kinerja Guru di Sekolah (Y)}

Hasil analisis hipotesis statistik $\left(\mathrm{H}_{0}\right)$ hubungan langsung iklim organisasi dengan kinerja guru diperoleh hubungan sebesar 0,485 dan mempunyai pengaruh langsung yang ditunjukkan standardized coefficient sebesar 0,012 dengan nilai signifikansi 5\%. Kesimpulan dari hasil tersebut adalah hipotesis statistik $\left(\mathrm{H}_{0}\right)$ diterima sedangkan hipotesis alternatif $\left(\mathrm{H}_{1}\right)$ ditolak hasil tersebut menunjukkan bahwa iklim organisasi tidak 
mempunyai hubungan langsung dengan kinerja guru maka jalur ini dihilangkan.

Hasil tersebut dapat dijelaskan sesuai dengan pendapat Higgins (1994:477) faktor yang berpengaruh terhadap iklim organisasi antara lain adalah manajer,tingkah laku karyawan, tingkah laku kelompok kerja dan faktor eksternal organisasi. Pendapat tersebut menunjukkan bahwa iklim organisasi dapat mempunyai hubungan tidak langsung dengan kinerja guru melalui motivasi guru dalam pendapat tersebut ditunjukkan dengan perilaku karyawan. Pendapat yang mendukung hasil tersebut dikemukakan oleh Gilmer dalam Hoy dan Miskel (1987) yang menyebutkan bahwa "iklim organisasi merupakan karakteristik yang membedakan satu organisasi dengan organisasi lainnya dan mempengaruhi orang-orang dalam organisasi tersebut". Dari pendapat tersebut dapat disimpulkan bahwa iklim organisasi mempunyai hubungan dengan kinerja guru.

\section{Hubungan Tidak Langsung Iklim Organisasi $\left(\mathbf{X}_{2}\right)$ dengan Kinerja $(\mathrm{Y})$}

melalui Motivasi Guru di Sekolah $\left(\mathbf{X}_{3}\right)$.

Hubungan iklim organisasi dengan motivasi guru adalah 0,690 dengan taraf signifikansi 5\%, hasil perhitungan koefisien jalur diperoleh nilai 0,459 dengan taraf signifikansi $0,000<0,05$, kemudian langsung antara motivasi dengan kinerja guru diperoleh hasil 0,625 dengan taraf signifikansi $5 \%$, hasil perhitungan koefisien jalur diperoleh nilai 0,475 dengan taraf signifikansi $0,000<0,05$. Hubungan tidak langsung variabel $\mathrm{X}_{2}$ dengan $\mathrm{Y}$ melalui $X_{3}$ adalah $0,559 \times 0,475=0,218$, kemudian pengaruh totalnya terhadap kinerja guru $(\mathrm{Y})$ sebesar 0,218+0,012= 0,23 . Kesimpulan dari hasil tersebut adalah hipotesis statistik $\left(\mathrm{H}_{0}\right)$ ditolak sedangkan hipotesis alternatif $\left(\mathrm{H}_{1}\right)$ diterima, hasil tersebut menunjukkan bahwa iklim organisasi mempunyai hubungan tidak langsung dengan kinerja melalui motivasi guru.

Hasil tersebut diperkuat oleh pendapat Litwin dan Stringer dalam tulisan Toulson dan Smith (1994:457) dimensi iklim organisasi terdiri dari tanggung jawab, identitas, kehangatan, dukungan dan konflikTanggung jawab 
adalah perasaan menjadi pimpinan bagi diri sendiri, tidak harus selalu mengecek ulang semua keputusan yang diambil ketika karyawan mendapat suatu pekerjaan, karyawan yang bersangkutan mengetahui bahwa itu adalah pekerjaannya.

\section{Hubungan Langsung Motivasi $\left(\mathbf{X}_{3}\right)$} dengan Kinerja Guru di Sekolah (Y)

Variabel $\left(\mathrm{X}_{3}\right)$ Motivasi kerja mempunyai hubungan dengan kinerja guru sebesar 0,625 dan mempunyai pengaruh langsung yang signifikansi ditunjukkan standardized coeffcient sebesar 0,470 dengan nilai signifikansi sebesar 0,000<0,05. Dari hasil tersebut kesimpulan yang diambil adalah hipotesis statistik $\left(\mathrm{H}_{0}\right)$ ditolak sedangkan hipotesis alternatif $\left(\mathrm{H}_{1}\right)$ diterima.

Hasil tersebut sesuai dengan pendapatMangkunegara faktor-faktor yang mempengaruhi kinerja, yang pertama adalah faktor kemampuan (ability), kemampuan terdiri dari kemampuan potensi IQ dan kemampuan reality (knowledge + skill). Kemudian faktor yang kedua adalah faktor motivasi, faktor motivasi diartikan suatu sikap pimpinan dan karyawan terhadap situasi kerja di lingkungan organisasinya.

\section{Simpulan}

Kesimpulan dalam penelitian ini yaitu, evaluasi akreditasi di sekolah dasar kecamatan sintang termasuk katagori baik, iklim organisasi di sekolah dasar kecamatan sintang termasuk dalam kriteria baik, motivasi guru di sekolah dasar kecamatan sintang termasuk dalam kreteria tinggi, kinerja guru di sekolah dasar kecamatan sintang termasuk dalam kriteria sangat baik, terdapat hubungan langsung evaluasi akreditasi dengan kinerja guru di sekolah, terdapat hubungan tidak langsung evaluasi dengan kinerja melalui motivasi guru di sekolah, tidak terdapat hubungan langsung iklim organisasi dengan kinerja guru di sekolah, terdapat hubungan tidak langsung iklim organisasi dengan kinerja melalui motivasi guru di sekolah, terdapat hubungan langsung motivasi dengan kinerja guru di sekolah

Hendakanya badan Akreditasi Nasional SD/MI mempertahankan 
evaluasi akreditasi serta lebih menyempurnakan lagi instrumen penilaian akreditasi tersebut dan Sebaiknya kepala sekolah memahami setiap tahapan akreditasi kemudian memberikan fasilitas, motivasi, dan supervisi kepada guru untuk terus meningkatkan kinerjanyaHendaknya guru selalu memiliki motivasi untuk bekerja dengan baik selalu mencari sumber belajar untuk meningkatkan kemampuan yang dimiliki sehingga kualitas pembelajaran akan meningkat dan bagi para peneliti yang akan melakukan penelitian tentang faktor yang mempengaruhi kinerja guru menambahkan variabel yang lain yang belum diteliti seperti pemberian reward atau punishment untuk meningkatkan kinerja guru serta melakukan penelitian dalam lingkup yang lebih luas.

\section{Daftar Pustaka}

Arikunto, S. 2006. Prosedur Penelitian Suatu Pendekatan Praktek. Jakarta: Erlangga.

Davis, Keith dan John W. Newstrom. 1985. Prilaku Dalam Organisasi. Jakarta : Erlangga.

Higgins, J. M. 1994. The Management Challenge ( $2^{\text {and }}$ ed). New York: Macmillan.
Hoy W.K dan Miskel C.G. 1987. Educational Administration Theory, Research, and Practice, New York: Random House.

Imron, A. 2012. Kebijaksanaan Pendidikan di Indonesia. Malang: Bumi Aksara

Peraturan Pemerintah No. 32 tahun 2013 tentang perubahan atas Peraturan Pemerintah nomor 19 tahun 2005 tentang Standar Nasional Pendidikan.

Prawirosentono, S. 2010. Manajemen Sumber Daya Manusia: Kebijakan Kinerja Karyawan: Kiat Membangun Organisasi Kompetitif Era Perdagangan Bebas Dunia (Edisi 2). Yogyakarta: BPFE Yogyakarta.

Rineka Cipta.

Robbins, S. P. 2001. Perilaku Organisasi Jilid I. Terjemahan Tim Indeks. 2003. Jakarta: PT Indeks Kelompok Gramedia.

Robbins, Stephen P. 2003. Prilaku Organisasi. Index. Jakarta.

Setyadin, B. 2005. Dasar-dasar Penelitian Ilmiah. Malang:Lembaga Penelitian UM.

Sugiyono. 2010. Statistika untuk Penelitian. Bandung: Alfabeta.

Toulson, P \& Smith, M. 1994. The Relationship between Organizational Climate and Employee Perceptions of Personnel management Practices. Journal of Public Management. Vol 23, Issue 3 (Fall): 453-469 
Tyson, S \& Jackson, T. 1992. The Essence of Organizational Behaviour: Perilaku Organisasi. Terjemahan Jacobus, D \& Prabantini, D. 2000. Yogyakarta: Andi.

Undang-Undang RI Nomor 20 Tahun 2003 tentang Sistem Pendidikan Nasional 2005. Jakarta: Sinar Grafika.

Uno, B.H. 2010. Teori Motivasi \& Pengukurannya. Jakarta: Bumi Aksara.

Wirawan. 2007. Budaya dan Iklim Organisasi: Teori, Aplikasi, dan Penelitian. Jakarta: Salemba Empat

Wirawan. 2009. Evaluasi Kinerja Sumber Daya Manusia: Teori, Aplikasi dan Penelitian, Jakarta: Salemba Empat. 